\title{
Do Corporate Governance Practices in One Jurisdiction Affect Another One? Lessons from the Panama Papers
}

\author{
Bryane Michael \\ University of Hong Kong, Hong Kong \\ bmichael@hku.hk \\ Say Goo \\ University of Hong Kong, Hong Kong \\ shgoo@hku.hk
}

\begin{abstract}
To what extent do corporate governance practices in one jurisdiction affect another? In this paper, we look at the way that Hong Kong's and the Mainland's corporate governance practices have co-evolved, along with offshore incorporations from both places. Drawing on empirical illustrations of the data using analytical techniques like differential equations and Fourier Spectral Analysis, we find a strong relationship across time between changes in corporate governance practices in both jurisdictions as well as offshore incorporations. Our data also support the idea of a theory-free equilibrium level of corporate governance (determined by market participants' own behaviour rather than by a theory-laden econometric model). We show that lethargy likely explains the persistence of corporate governance practices in both places, with innovations in one place correlating with innovations in the other. Such work clearly implies that corporate governance improvements in one place can help encourage such improvements in other markets which have not adopted laws aimed at improving corporate governance.
\end{abstract}

\section{Keywords}

Chinese corporate governance - Panama Papers - corporate governance spillovers differential equations - Fourier spectral analysis 


\section{Introduction}

Are corporate governance practices "contagious"? Previous academic attention has turned to factors such as the influence of foreign directors serving on corporate boards in other countries. ${ }^{1}$ Or large foreign investors buying shares across borders. ${ }^{2}$ Foreign listing rules also have a role to play. ${ }^{3}$ Yet, few academics - with the exception of legal authors like Gilson $(2001)^{4}$ and Branson $(2001)^{5}$ - have looked at the dynamics of such influence. Some authors like Gourevitch and Shinn $(2005)^{6}$ might see corporate governance as the result of a transnational political contest, where the rich and powerful take over and write (rewrite) corporate governance codes to suit their own selfish purposes. Yet, beyond the case studies populating this literature, we hardly know what effect corporate governance reforms (on paper and in practice) have across borders. Most descriptions of corporate governance influence across borders (except in the very narrow context analysed by economists) have yet to be rigorously, econometrically tested.

In this paper, we quantify the mutual influence of corporate governance rules and practices between Hong Kong and the Mainland (the People's Republic of China). ${ }^{7}$ We use the rare glimpse at corporate governance practices afforded by the Panama Papers to find correlations between the way each/both jurisdictions use offshore incorporations and their differing corporate governance

1 Masulisa, Ronald, Cong Wang and Fei Xie, Globalizing the Boardroom-The Effects of Foreign Directors on Corporate Governance and Firm Performance. Journal of Accounting and Economics 53(3) (2012): 527-554.

2 Gillan, Stuart and Laura Starks, Corporate Governance, Corporate Ownership, and the Role of Institutional Investors: A Global Perspective. Journal of Applied Finance 13(2) (2003).

3 Bell, Greg, Igor Filatotchev and Ruth Aguilera, Corporate Governance and Investors' Perceptions of Foreign IPO Value: An Institutional Perspective. Academy of Management $57(1)(2014): 301-320$.

4 Gilson, Ronald, Convergence of Form or Function. American Journal of Comparative Law 49(2) (2001): 329-358.

5 Branson, Douglas, The Very Uncertain Prospect of Global Convergence in Corporate Governance. Cornell International Law Journal (2001): 34:321.

6 Gourevitch, Peter and James Shinn, Political Power and Corporate Control: The New Global Politics of Corporate Governance. Princeton Press, 2005.

7 We do not refer to official territory names to keep our paper readable. Thus, we do not express any kind of political views when we refer to China as the Mainland (as the Hongkongers do) or simply China in contrast to its special administrative region of Hong Kong. We discuss briefly below why Hong Kong's Basic Law allow the territory autonomy in running its own legal system and corporate law. 
rules. ${ }^{8}$ Hong Kong contributes to some of the poor corporate governance on the Mainland - given Mainland companies' use of Hong Kong and offshore incorporation centres to mislead investors at home and abroad. Hong Kong has also contributed to some improvements in corporate governance, through Chinese companies copying/complying with Hong Kong corporate governance standards. Indeed, such an interaction has reflected the popular view of corporate governance reform as following a golden mean (balancing inside owners' interests with others, while not reforming too quickly or slowly). Corporate governance practices in one jurisdiction thus do affect another jurisdiction (at least in our limited context) —and we leave to others to figure out the exact mechanisms of such an affect.

The limited space afforded by journal publication forces us to restrict our discussion in several ways. First, and most importantly, we do not structure our paper in the usual scholarly way. We engage with the literature during our analysis (rather than before in a literature review). We also write the paper like an essay, rather than a scientific paper, to make an argument larger than simply testing a narrow hypothesis, while still grappling with the literature. As such, we don't write out formulas for our econometrics techniques nor report confidence intervals (which are done by software anyway). Our argument supersedes our desire to find exact parameter estimates and so forth. Second, we only describe the links between offshore incorporations and corporate governance (as measured by crude aggregate measures). In a larger working paper version of this paper, we go into the corporate governance details that we have no space here to discuss. Third (and relatedly), we treat offshore incorporation as a corporate governance issue-a reflection of poor corporate governance in companies electing to set up offshore entities as well as a vector for allowing poor corporate governance practices to continue. ${ }^{9}$ To readers and reviewers anxious to critique us for omitting such a discussion, we would refer them to the larger online working paper. Fourth, we do not develop and test a model of such corporate governance propagation. Following post-classical (critical

8 We refer to the Panama Papers data in this paper as data from the International Consortium of Investigative Journalists' (ICIJ) Offshore Leaks Database. The database includes information from the Panama Papers, the Offshore Leaks and the Bahamas Leaks. Yet, we refer to Panama Papers only as a short-hand for these combined search results to make our paper easier to read.

9 O'Donovan and his co-authors (2017) have conducted analyses similar to those in the larger working paper version of this paper, econometrically valuing the lapses in corporate governance allowing corporate owners and managers to profit from "offshore secrets." O'Donovan, James, Hannes Wagner, and Stefan Zeume, The Value of Offshore Secrets-Evidence from the Panama Papers. Asian Bureau of Finance and Economic Research 2050 (2017). Available online. 
school) critiques of the corporate governance literature, we do not impose a model or world-view on the data-letting the data tell their own story. ${ }^{10} \mathrm{We}$ appreciate the conventional approach to empirically describing and testing corporate governance hypotheses. Yet, our project consists only in showing a link between changes offshore incorporations, the quality of corporate governance (writ large however imperfectly measured) across borders-while commenting on what these changes imply for the corporate governance literature. Fifth, and again related to the previous point, Hong Kong hardly represents a foreign jurisdiction from China. Yet, we would argue that differences in legal tradition, political institutions (which drive poor corporate governance on the Mainland) and even language make Hong Kong a sufficiently foreign enough jurisdiction for our purposes. ${ }^{11}$

\section{Background: Chinese Firms' Corporate Governance and Offshore Incorporation Centres}

Bad corporate governance represents a key factor in Chinese companies' using the services of offshore secrecy jurisdictions' intermediaries and the services of organisations like Mossack Fonseca. ${ }^{12}$ Media accounts paint a picture of Chinese companies' ways and needs to use Mossack Fonseca (specifically) and offshore incorporation agents (in general). Figure 1a shows some of the facts linked with Chinese and Hong Kong incorporations (and corporate governance) cited in the Mossack Fonseca case for the reader unfamiliar with the details. Clearly, Hong Kong' corporate governance laws and practices facilitated

10 Yoshikawa, Toru and Abdul Rasheed. (2009). Convergence of Corporate Governance: Critical Review and Future Directions. Lee Kong Chian School of Business Research Collection 5-20og. Available at: http://ink.library.smu.edu.sg/lkcsb_research/2908/

11 La Porta and his colleagues (1998) still represent the orthodoxy in corporate governance research, defining different corporate governance practices by legal origins and institutions characteristics. By their measure then, Hong Kong's "distance" from China would suffice to make the jurisdiction's corporate governance practices interestingly different and autonomous. La Porta, Rafael, Florencio Lopez de Silanes, Andrei Shleifer, and Robert Vishny, Law and Finance. Journal of Political Economy 106(6) (1998): 1113-1155.

12 The International Consortium of Investigative Journalists (2016) describe in detail the "Panama Papers scandal" - the moniker given by the global media industry to the leak of the Panama-based law firm Mossack Fonseca's client data, leading to revelations about the use of offshore companies. 
What is a shell company? - A non-trading corporation (or entity with tradable/transferrable interests) that does not conduct significant operations related to the transformation of inputs into marketable outputs.

Why are shell companies valuable for China's businesses?- - Roughly $40 \%$ of private Chinese firms hide profits. ${ }^{a}$ Over $\$ 1$ tn originated from China from 2002 to 2012, making China the world's largest illicit capital exporter. $^{\mathrm{b}}$ If Chinese firms benefitted as much as other firms, they can take capital gains profits of up to $50 \%$ quickly from listing abroad. ${ }^{\mathrm{c}}$

Revenue from shell company sales-Mossack Fonseca probably collected around $\$ 8.2$ million in fees for opening the 16,300 offshore companies incorporated in offices in China and Hong Kong, or roughly $30 \%$ of its "active companies worldwide".

Companies' management identified in the Papers-Tencent, Soho China property, Yintai, Leshi (web video), GOME appliances chain, Oceanwide, Tiens Group, Zendai investment group, Rizhao Holding, Shenzhou international, Sound global, Soundtech, Shanghai Land Holdings, and Country Garden Holdings (Walker et al., 2016). ${ }^{\mathrm{e}}$

Mossack Fonseca in Hong Kong-Much business handled by P\&P Secretarial Management and its British Virgin Islands registered interest Harvest Sun Trading. An accountant Wai-hon Chiu, runs P\&P. ${ }^{\text {f Roughly }}$ comprising $1 / 3$ of all Mossfon business in Hong Kong for Mainland customers, Wong Brothers \& Co. helped an influential family to set up a BVI shell company.g At its apogee, the firm set up 2,428 companies (in 2012).

What is the problem?- - Recent estimates put $10 \%$ of all reverse merger listings of Chinese companies in the US as fraudulent. ${ }^{\text {h }}$ The Panama Papers implicate HSBC, a large bank with a significant presence in Hong Kong, in setting up roughly 2,300 accounts—contravening banking regulations. ${ }^{\text {i }}$ Sun Hung Kai Properties (another large Hong Kong company) could spirit away large amounts of money, even though intermediaries know the director had been convicted of corruption. ${ }^{j}$ Money laundering remains rampant in Hong Kong - fragilizing the entire financial system. ${ }^{\mathrm{k}}$ Roughly $60 \%$ of all investment - some the result of crime or contravening foreign exchange controls- passes through Hong Kong on its way out from China. ${ }^{1}$ In general, Chinese firms incorporating in offshore havens participate in more fraud and earn shareholders less in the longer-run. ${ }^{\mathrm{m}}$

FIGURE 1A Chinese corporations' participation in Mossack Fonseca's shell game Notes:

a While authors like Liu and Xiao (2004) cite data now almost 15 years old (and older), these trends have not changed in the intervening decade.

b Mulrenan, Stephen, Asia: Panama Papers—No News Is Good News. International Bar Association Global Insight June 2016. Available online.

c Such "listing" refers to the reverse mergers (or backdoor listing). Floros, Ioannis and Travis Sapp, Shell Games: On the Value of Shell Companies. Journal of Corporate Finance 17 (2011); Brown, Philip, Andrew Ferguson and Peter Lam, What's in a Shell? Analysing the Gain to Shareholders from Reverse Takeovers. SSRN Working Paper 1896004(2010), Available online.

d Agence France Presse, Money and Power: China Government's Link to Panama Papers Firm, Hong Kong Free Press April, 2016, available online.

e This list does not include the economic interests associated with the eight current or former members of China's Communist Party's Politburo Standing Committee. Walker, Marina, Gerard Ryle, Alexa Olesen, Mar Cabra, Michael Hudson and Christoph Giesen, Leaked Records Reveal Offshore Holdings of China's Elite. ICIJ January 2018. Available online. 
f Kinetz, Erika and Kelvin Chan, Hong Kong Emerges As Hub for Creating Offshore Companies. Associated Press Big Story April 2016. Available online.

g Mossfon refers to the popular media's (and the company's own) abbreviation of Mossack Fonseca's name for brevity. See Lau, Stuart, Revealed: Panamanian Law Firm Mossack Fonseca's Man in Hong Kong. South China Morning Post April, 2016, Huang, Zhe-Ping, The Panama Papers: China's elite are linked to offshore deals that hid millions of dollars. Quartz: Obsession 2016. Available online.

h Tax Justice Network. (2011). 1 in 10 reverse mergers of Chinese firms on US stock exchanges "fraudulent". Available online.

i Floyd, David, Panama Papers: Top 10 Banks For Offshore Companies, 2016. Available online.

j Robertson, Joshua and Paul Farrell, How a Hong Kong corruption scandal sparked strife at Mossack Fonseca. Guardian April 2016. Available online.

k Holland, Tom, How Hong Kong makes it easy for wealthy Chinese to Launder Billions of Dollars. Hong Kong Free Press April 2016. Available online.

l Garcia-Herrero, Alicia, Le Xia and Carlos Casanova, Chinese outbound foreign direct investment: How much goes where after round-tripping and offshoring? BBVA Working Paper, 15/17, 2015; Kar, Dev and Sarah Freitas, Illicit Financial Flows from China and the Role of Trade Mis-invoicing. Global Financial Integrity (2012). Available online.

$\mathrm{m}$ As if the belabour the point, Siegel and Wang (2014) show how incorporation in an offshore haven like Nevada correlates with fraud more often for Chinese companies engaging in backdoor listings in the US. Siegel, Jordan and Yan-Bo Wang, Cross-Border Reverse Mergers: Causes and Consequences. Harvard Business School Publication 12-089 (2014). Available online.

SOURCE: SEE FOOTNOTES FOR SOURCES

the use of offshore vehicles as a method for enabling and prolonging poor corporate governance at home and in China (among other foreign jurisdictions). ${ }^{13}$

To what extent have Hong Kong-based intermediaries participated in the creation of offshore corporate vehicles for Mainland companies (and those at home)? Figure $1 \mathrm{~b}$ shows, using data from the International Consortium of Investigative Journalists (ICIJ, 2016), ${ }^{14}$ the time line highlighting the height of the popularity of different locations for the intermediaries who create offshore companies. Panamanian intermediaries saw their heyday in the early 1990 s for Hong Kong and Mainland clients. The Bahamas opened more offshore companies a few years later than subsequently in the 2000 s and $2010 s$.

13 Naturally, offshore entities facilitate legal, welfare-increasing transactions as well as illegal, selfish ones. We refer the reader to authors like Bailey and Liu (2013) for the theory and data around the use of offshore entities and its effect on corporate governance-and vice versa. Bailey, Warren and Edith Liu, Incorporation in Offshore Financial Centers: Naughty or Nice? SSRN Working Paper 2357074 (2013). Available online.

14 International Consortium of Investigative Journalists. (2016). The Panama Papers: Politicians, Criminals and the Rogue Industry that Hides Their Cash. Available online. 


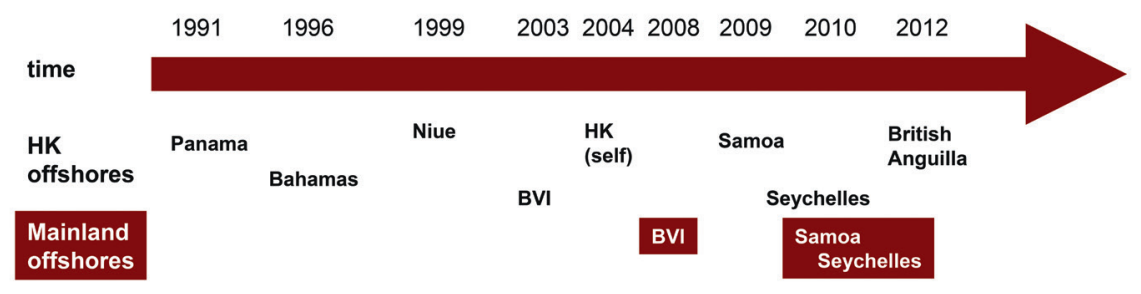

FIGURE 1B Offshore of choice went in waves for Hong Kong and Mainland offshore companies

Note: The figure shows the average year of incorporation for offshore companies handled by Mossack Fonseca and the companies implicated in the Offshore Leaks files for Hong Kong and Mainland. The figure also shows the jurisdiction of incorporation. Despite the differences in average date and place of incorporation, the BVI accounted for roughly $60 \%$ of Hong Kong's offshores and $50 \%$ of Chinese respectively.

SOURCE: ICIJ (2016).

The unheard-of Niue (a microscopic island in the South Pacific) also saw a brief rise in these incorporations. ${ }^{15}$ The British Virgin Islands (or BVIs) saw their heyday as a key incorporator of offshore companies around 2003. While BVI continues to handle most of Hong Kong and the Mainland's offshore incorporations, other jurisdictions (notably Samoa, Seychelles and British Anguilla in recent years) have succeeded in gaining more market share than in the past. The practices of opening and using offshore vehicles, which served Hong Kong's corporations well, also helped serve their Chinese counterparts.

Such offshore incorporations have benefitted corporates in a wide range of China's cities (and the businesses/businesspersons in them). Figure 2 shows the location of offshore intermediaries' Mainland clients. Unsurprisingly, most demanders of offshore companies hailed from Beijing and Shanghai. Yet, even companies and individuals in Foshan and Nanchang participated in the offshore incorporation market. As this geography shows, demand for offshore companies spread around China as a way of evading taxes, bypassing capital controls, and safeguarding personal/company assets from seizure by law enforcement. ${ }^{16}$ Other sources provide data about China's high net worth individuals, supporting the conclusion of increasing geographical dispersion

15 Van Fossen (2012) talks about the brief rise and fall of Niue as an offshore financial centre. Clearly, Hong Kong and Mainland clients shared in that rise and fall. Van Fossen, Anthony, Chapter 2. In Anthony Van Fossen. Tax Havens (2012).

16 Henry, James, The Price of Offshore Revisited: New Estimates For “Missing” Global Private Wealth, Income, Inequality, and Lost Taxes. Tax Justice Network Working Paper, July 2012; Alstadsaeter, Annette, Niels Johannesen, and Gabriel Zucman, Who Owns the Wealth 


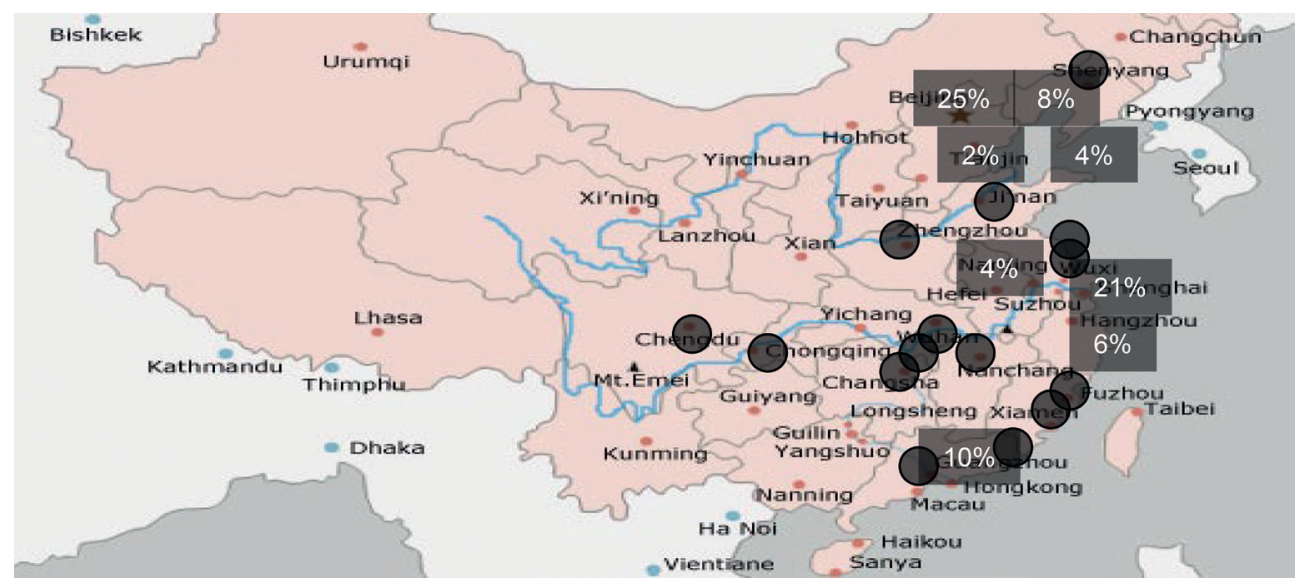

FIGURE 2 Mainland offshore clients by location

Note: The graph shows the city of addresses of clients listed in the Panama Papers and Offshore Leaks. We show the percent of clients from a place during the time period covered by these databases. The round dots indicate places with $1 \%$ of the total client roster.

SOURCE: ICIJ (2016).

in the use of offshore companies and wealth. ${ }^{17}$ Figure 3 provides a simple illustration of the link between offshore incorporations and wealth on the Mainland. Random chance can not explain the very tight fit between the number of offshore incorporations in selected Chinese cities and the number of millionaires in those cities. ${ }^{18}$ We can not know for sure which factor represents the chicken ... and which the egg (the independent versus dependent variable). Yet, we do know that wealth in China correlates with the use of offshore entities often incorporated in Hong Kong (whose use represents a corporate governance defect under Communist Party rules, abets the laundering of monies resulting from such corporate governance defects, and reduces incentives for improving such governance) ${ }^{19}$

in Tax Havens? Macro Evidence and Implications For Global Inequality. NBER Working Paper 23805 (2017). Available online.

17 Hurun Research Institute, Hurun Wealth Report 2014 (2014). Available online.

18 In other words, the probability that no correlation exists between these variables does not significantly differ from zero. We do not show the exact statistics related to testing whether the correlation is zero-as this unnecessarily complicates our paper.

19 In our larger working paper, we show econometric evidence from authors like Liu and co-authors (2012) showing that better corporate governance increases Chinese companies' profits in the longer-term. Liu, Chun-yan, Konari Uchid and Yu-feng Yang, Corporate governance and firm value during the global financial crisis: Evidence from China. International Review of Financial Analysis 21 (2012): 70-80. 


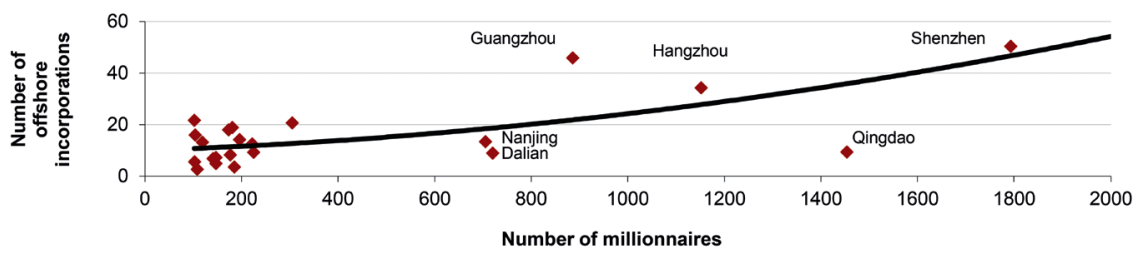

FIGURE 3 Offshore incorporations as cause and effect of the rise in Chinese millionaires around the country

Note: The figure shows the correlation between the number of clients of offshore incorporation services and the number of millionaires in 24 key Chinese cities. Fitting a line between these two variables helps explain roughly $96 \%$ of the variation in the data.

SOURCE: ICIJ (2016) AND HURUN RESEARCH (2016).

How do we know that Chinese companies' poor corporate governance results in malfeasance like tax evasion? As early as 2004, authors like Liu and Xiao (2004) found significant tax avoidance among Chinese companies of up to $16 \%$ of profits. Private firms report profits rates of around $8 \%$. Other types of firms reporting profits of only $4 \%$ probably mis-represent their profits. ${ }^{20}$ If only ownership types differ between these companies, we can deduce that, on average, these other (non-private) firms must be hiding $4 \%$ of their profits (Ibid., Figure 1). Such under-payment defies the received wisdom about soes' tax payments - as they may indeed, seek to pay taxes, given these taxes' effect on soE managers' promotion potential. ${ }^{21}$ Namely, the Communist Party taps high tax-paying SOE-managers for promotion and other benefits more frequently. In their summary of the literature, Jansky and Prats (2013) find that ties to a tax haven often provide enough of a predictor of tax avoidance/evasion. ${ }^{22}$ They do not have data for China. But if countries like India serve as a possible comparator, firms with linkages to tax havens pay 30\% less tax than companies without these links. Fisman et al. (2008) specifically for their part of this story, find that traders use "offshore" Hong Kong as a way to avoid paying Chinese

20 Liu, Qiao and Geng Xiao, Look Who Are Disguising Profits: An Application to Chinese Industrial Firms. Hong Kong Institute of Economics and Business Strategy Working Paper 1095 (2004). Available online.

21 Zhang, Huai, How Does State Ownership Affect Tax Avoidance? Evidence from China. Singapore Management University School of Accountancy Working Paper \#2012/13-18 (2013). Available online.

22 Jansky, Petr and Alex Prats, Multinational Corporations and the Profit-Shifting Lure of Tax Havens. Christian Aid Occasional Paper Number 9(2013). Available online. 


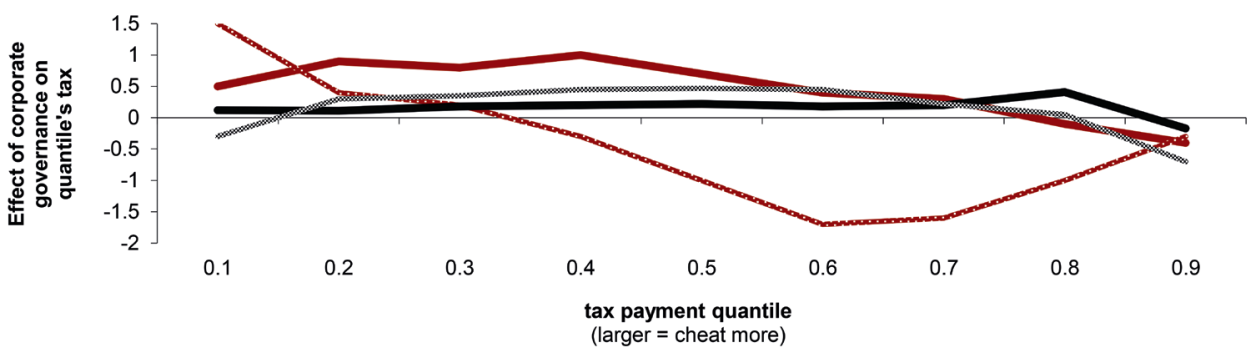

\begin{tabular}{|l|}
\hline Tax paid in tenths with FiNANCIAL EXPERTS \\
Tax paid in tenths with INDEPENDENT
\end{tabular}

FIGURE 4 Corporate governance helps big Chinese tax-cheats cheat more and small ones to pay more tax

Note: The figure shows the effect of two corporate governance interventions (introduction of financial experts and independent directors on Chinese companies' boards). Unlike normal regression, this chart shows the effect of corporate governance on each quantile of tax payers/cheaters.

SOURCE: ARMSTRONG ET AL. (2015).

taxes and tariffs. ${ }^{23}$ Hong Kong serves as a key channel for spiriting away evaded tax proceeds.

What effect would better corporate governance thus have on reducing practices like tax evasion? Figure 4 shows the effects of putting more financial experts and independent directors on corporate boards in general. If these results apply to China in the same way as the US, corporate governance reforms like these probably encourage tax paying behaviour for companies not already heavily engaged in tax evasion. Yet, for those companies which evade large shares of tax, more comprehensive corporate governance reform seems to correspond to more tax cheating. Desai and Dharmapala (2005) find that increases in tax avoidance leads to increases in Tobin's $q$ of around $2.5 \%$ only with better governed firms. ${ }^{24} \mathrm{Kim}$ and co-authors (2010) find that stock prices become more resilient against crashes by around 0.2 as tax avoidance decreases (as companies pay more taxes). ${ }^{25}$ Figure 5 shows the counter-intuitive relationship between corporate governance and tax evasion found in much of

23 Fisman, Raymond, Peter Moustakerski, and Shang-Jin Wei, Outsourcing Tariff Evasion: A New Explanation for Entrepot Trade. The Review of Economics and Statistics 9o(3) (2008). Available online.

24 Desai, Mihir and Dhammika Dharmapala. Corporate Tax Avoidance and Firm Value. NBER Working Paper Series Working Paper 11241. Available online.

25 Kim, Jeong-Bon, Ying-Hua Li, and Lian-Dong Zhang, Corporate Tax Avoidance and Stock Price Crash Risk: Firm-Level Analysis. Journal of Financial Economics (2010). Available online. 


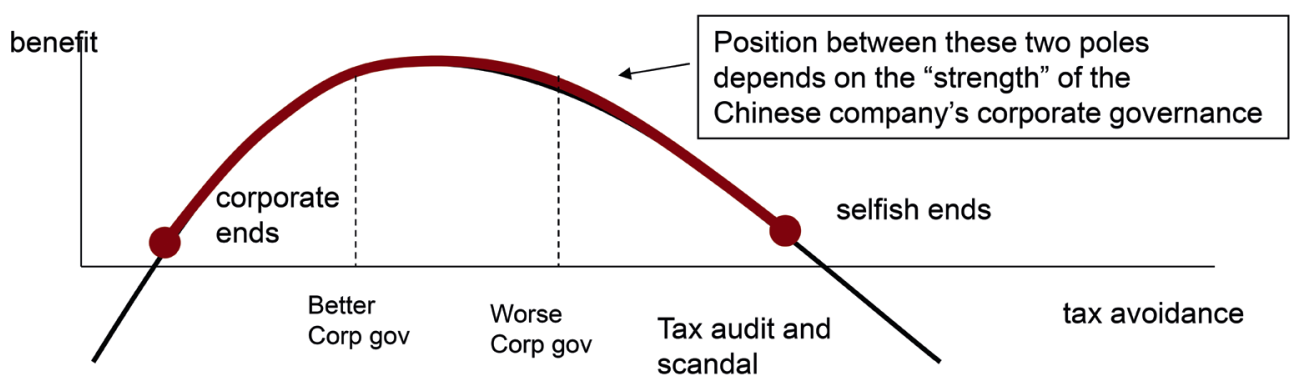

FIGURE 5 Corporate governance determines the level of tax benefits and the distribution between selfish versus business ends

Note: The figure shows a simplified representation of the relevant literature looking at the relationship between tax evasion and company "benefits" (net of corporate-governance-related spending and as defined in each study). Corporate governance reforms seek to obtain benefits by curtailing tax avoidance. Such reform in very misgoverned companies would likely contribute to further tax avoidance (and other forms of corporate mal-governance).

SOURCES: SEE TEXT FOR SOURCES CITED.

the literature. Better corporate governance of course leads to less tax evasion. Yet, these data also show that corporate governance can-for badly governed companies - contribute to tax evasion and other criminal behaviour. More generally, an expected or middle-level value of corporate governance reform best serves corporate interests ... resulting in middling levels of malfeasance (John and Kedia, 2002). ${ }^{26}$

What Do the Panama Papers Data Show about China's Corporate Governance?

The Mossack Fonseca and Open Leaks data provide some indication about the relationship between corporate governance and the use of offshore structures in Hong Kong and the Mainland. Figure 6 shows the percent change in offshore account openings as corporate governance scores for the jurisdiction improve - with corporate governance data taken from the World Economic Forum (2016). ${ }^{27}$ Of course, they data reflect a very crude measure of corporate governance. Yet, if true, Mainland account openings increased at a time when corporate governance had improved—-suggesting that perhaps other factors

26 John, Kose and Simi Kedia, Institutions, Markets and Growth: A Theory of Comparative Corporate Governance. NYU Working Paper No. CLB-o6-02o (2006). Available online.

27 World Economic Forum, Competitiveness Rankings 2015-2016 (2016). Available online. 


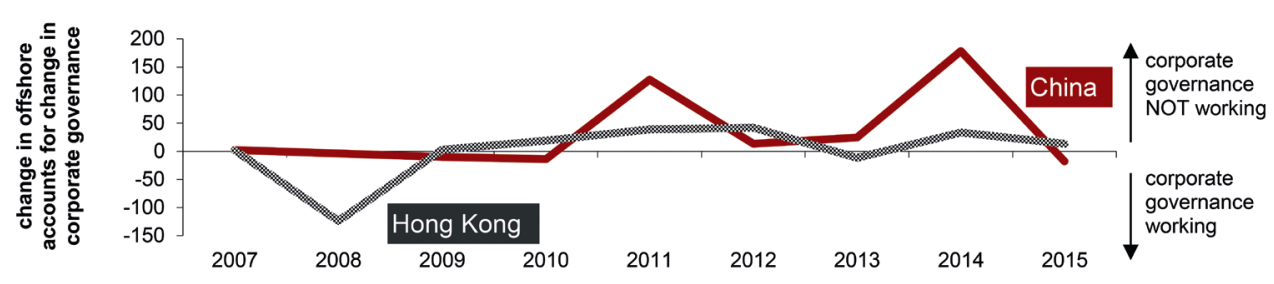

FIGURE 6 Better corporate governance in Hong Kong and China coincided with more Mossack Fonseca registered offshore accounts

Note: The figure shows the annual percentage change in offshore accounts opened with Mossack Fonseca from China and Hong Kong, for each of the periods shown, divided by the annual percent change in a corporate governance quality index derived from the World Economic Forum. In other words, we show the elasticity of offshore accounts with respect to changes in corporate governance. The corporate governance index simply adds up the elements from Pillar I Section B of the World Economic Forum's data. Positive numbers mean more offshore accounts opened while corporate governance scores improved.

SOURCE: ICIJ (2016) AND WEF (2016).

(besides corporate governance) contributed to these account openings. Hong Kong based intermediaries opened fewer offshore accounts during the same time period. Figure 7 indeed shows that Hong Kong offshore account openings decreased during the time when the number of Chinese accounts rose. Figure 8 shows that other jurisdictions had reduced their offshore incorporations during a time of relatively stable corporate governance. Thus, Mainland offshore incorporations thus might have made up for the decreases in other jurisdictions.

A bit more analysis shows other trends and patterns in the interactions between corporate governance and offshore incorporations in Hong Kong and the Mainland. Figure 9 shows the relationship between the rate of change of improvements in the Mainland's corporate governance and its levels of offshore incorporations. Once Chinese companies go down the road of improving their corporate governance, they will likely continue to do so. Such improvements furthermore correlate with less demand for offshore incorporations. The only "viable" corporate governance programmes rate a 34.5 or higher. At such a take-off level (as we label in the figure), corporate governance leads to sustainable decreases in offshore incorporations and self-improving corporate governance. Figure 10 shows similar data for Hong Kong - with different results. Hong Kong's stable corporate governance rates hover at around 48.2 (or 14 points higher than their Mainland counterparts). Interesting, better corporate governance in Hong Kong seems to correlate with more demand for offshore incorporations. Yet, Hong Kong companies' demand for offshore 


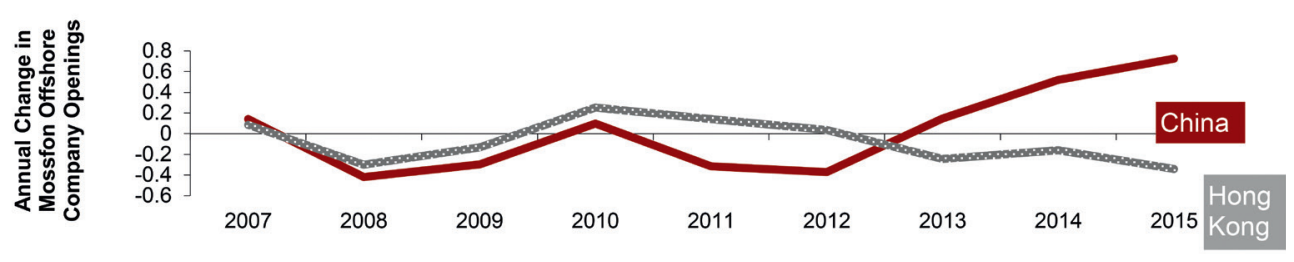

FIGURE 7 Have changes to Hong Kong's corporate governance and money laundering regulations caused offshore companies registrations to move over the border? Note: The figure shows the annual change in the number of offshore entities registered by Mossack Fonseca from Hong Kong and China for the years shown. Registration rates paralleled each other in Hong Kong and the Mainland until the passage of wide-sweeping reforms to Hong Kong's Corporate Governance Code and the passage of several anti-money laundering regulations. The increase in Chinese offshore registrations coinciding with Hong Kong's decline suggest clients previously opening these accounts in Hong Kong moved to the Mainland. SOURCE: ICIJ (2016).

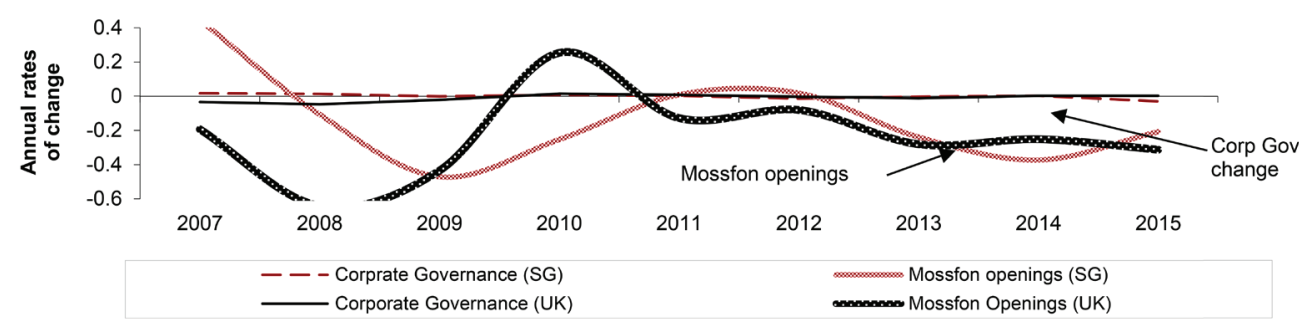

FIGURE 8 Singapore and UK had small and steady improvement in corporate governance with large declines with Mossack Fonseca openings

Note: The figure shows the annual change in corporate governance quality in Singapore and the UK along with the change in offshore incorporations handled by Mossack Fonseca. The corporate governance indicator represents the sum of World Economic Forum indicators Pillar I, Section B. Corporate governance scores changed little (and for the better) while the number of Mossfon incorporations fell by large amounts in many recent years.

SOURCE: ICIJ (2016) AND WEF (2016).

incorporations increases most with the relatively rapid deterioration of their corporate governance ratings from high levels of corporate governance to lower levels.

What about the relationship between Hong Kong and the Mainland? What proof exists that Hong Kong somehow contributes (or not) to the Mainland's corporate governance and offshore incorporation practices? Figure 11 shows some initial evidence for such a relationship. Unsurprisingly, bad corporate governance in Hong Kong correlates with bad governance on the Mainland - and 


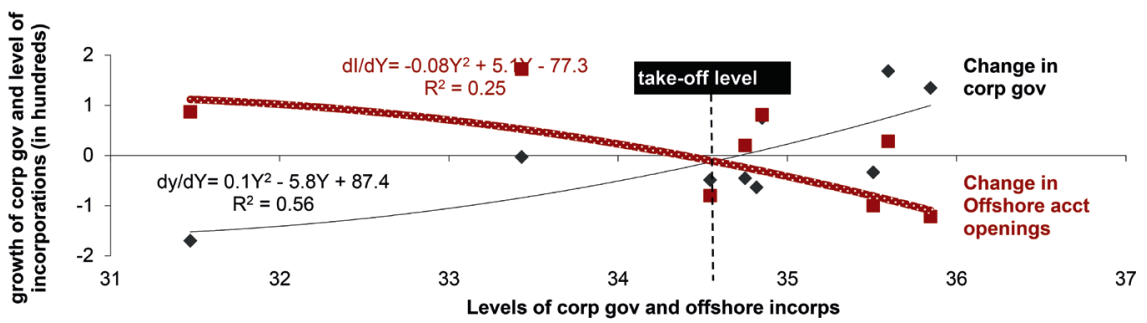

FIGURE 9 China's corporate governance growth depends on already existing levels and offshore incorporations fall in China as corporate governance levels rise Note: The figure shows the relationship between the way that corporate governance and offshore incorporations change as corporate governance levels increase. Good corporate governance breds better governance and fewer offshore incorporations encourage further decreases in offshore incorporations. The marginal change in corporate governance seems to balance the change in offshore incorporations at around 34.7. Below that point, corporate governance is too low to promote change. SOURCE: DATA FROM ICIJ (2016).

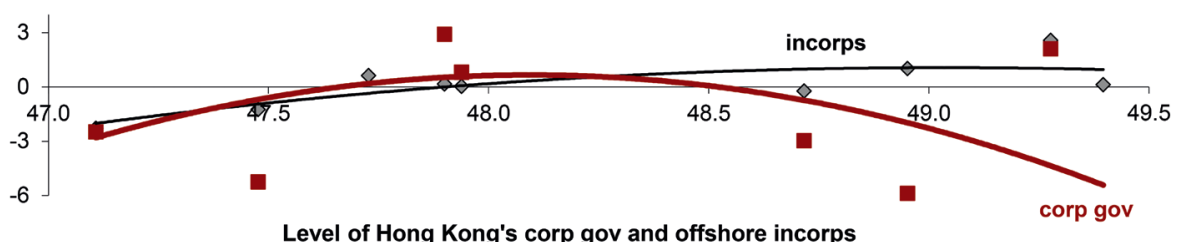

FIGURE 10 Hong Kong's changes in corporate governance and offshore incorporations stable for bad as well as good levels of corporate governance (in other words, exhibit double equilibria)

Note: The figure shows the extent to which levels of corporate governance influence changes in Hong Kong's corporate governance and offshore incorporations. Corporate governance should remain stable-ish at levels of 47.5 and 48.5. Yet, better corporate governance seems to encourage more offshore incorporations. The most rapidly falling corporate governance unsurprisingly correlates with the fastest growth in offshore incorporations. SOURCE: ICIJ (2016).

visa-versa. Yet, a range of Hong Kong "bad boys" exists for companies scoring between 47.5 to 48.75 . When Hong Kong companies have corporate governance in this range, corporate governance on the Mainland falls the fastest. Moreover, Mainland companies can expect a deterioration in their corporate governance to the low value of the range (namely 47.5), as they deal with relatively unreliable partners? Differences-in-differences analysis (between China and Hong Kong and before versus after corporate governance reform) shows 


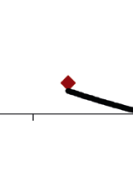

47

47.5

48

48.5

49.5

50

level of Hong Kong's corporate governance

FIGURE 11 China's corporate governance reform (change) depends on the quality of corporate governance in Hong Kong

Note: The figure shows the way that Mainland corporate governance changed over time as the level of Hong Kong's corporate governance improved in the postListing Rules-reform era. More advanced time series estimation validates this relationship (and the line of best fit anyway explains $83 \%$ of the variation in the data). One way of improving corporate governance on the Mainland thus consists of improving it in Hong Kong. Middling levels of Hong Kong's corporate governance seem worst for Chinese governance — as low and high levels push Chinese companies to do better.

SOURCE: DATA FROM ICIJ (2016).

a 3 point improvement in the Hong Kong's corporate governance during the time of Corporate Governance Listing Rules - showing that such changes do affect corporate governance. ${ }^{28}$

Network analysis of the Panama Papers database points most strongly to the way that Hong Kong contributes to China's corporate governance travails. Figure 12 shows the way that offshore entities incorporated by Mossack Fonseca (or other agents in the ICIJ database) link to the jurisdictions shown in the figure. If Chinese companies simply used Hong Kong based incorporation agents to spirit funds offshore, we would expect strong links mainly between these two jurisdictions. We see though, that both jurisdictions have many jurisdictions in common - with many BVI entities starting in Hong Kong and ending on the Mainland (for example). Some jurisdictions relate primarily to one jurisdiction or the other (like the Cook Islands and Hong Kong. Yet, Hong Kong and the Mainland have more links with these other jurisdictions than either random luck or other jurisdictions' experiences would suggest. ${ }^{29}$

28 Differences-in-differences analysis represents a fancy way to say that we subtracted corporate governance scores before the Governance Listing Rules changes from those scores after the changes and then subtracted these differences for Hong Kong from China. By including China in the calculation, we control for its effect (and thus the effect of broader economic factors).

29 We test this by looking at the probability distributions that govern Singapore's, Taiwan's, Thailand's and the UK's links with other offshore jurisdictions (choosing these jurisdictions as the major rivals to Hong Kong). We also look at a random probability distribution. 


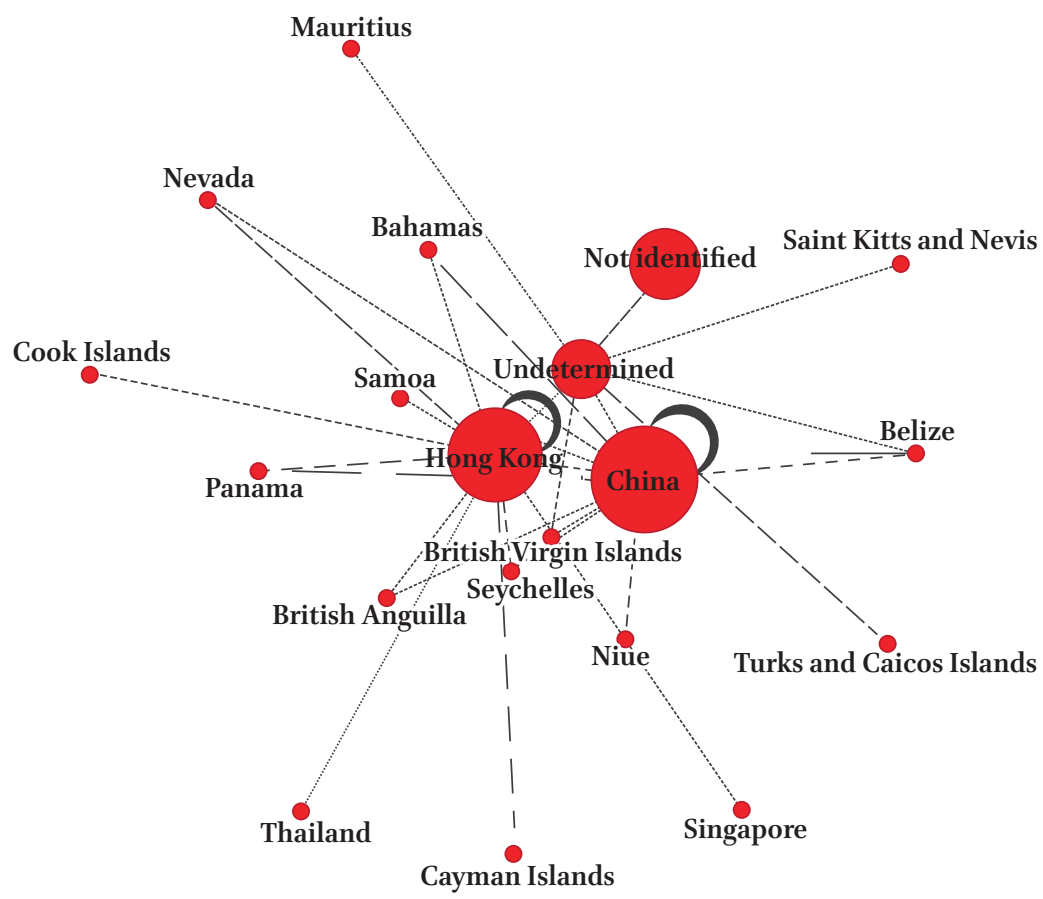

FIGURE 12 Hong Kong and China share far more business with the same jurisdictions than coincidence can explain

Note: The figure shows the links between the offshore entities in the jurisdictions shown for Hong Kong and China. We downloaded the ICIJ data for Hong Kong and China, ran them through network analysis software, and looks for patterns. The links between China-Third Party-Hong Kong occur far more likely than random variation would allow (and more than we see in other pairs of jurisdictions like US/UK or Singapore/Malaysia etc.). The number of 'undetermined' and 'nonidentified' jurisdictions (even in the Mossack Fonseca data!) seem disconcerting. SOURCE: BASED ON DATA FROM THE ICIJ (2016). ICIJ, OFFSHORE LEAKS DATABASE, 2016, AT SEARCH JURISDICTIONS FOR CHINA AND HONG KONG, AVAILABLE ONLINE.

Overlapping decisions to use particular jurisdictions at particular times suggest that Hong Kong and China form poles in a broader network of offshore corporate relations, which likely "layer" across numerous jurisdictions. ${ }^{30}$

We find that "attraction" between China and Hong Kong explains the increased incidence of linking with these other jurisdictions. Jurisdictions which Hong Kong clients use tend to link to the Mainland more often (and visa versa).

3o To keep our paper from being too technical, we do not report the correlations between the extent to which Hong Kong and Mainland firms use particular jurisdictions in particular years. As we illustrated informally above, jurisdictions like Niue attracted waves of 


\begin{tabular}{|c|c|c|c|c|c|c|c|c|c|c|}
\hline $\begin{array}{c}\text { Jurisdiction } \\
1 \\
(\mathbf{X})\end{array}$ & $\begin{array}{l}\text { CG/ } \\
\text { PP }\end{array}$ & & $\begin{array}{c}\text { Jurisdiction } \\
\mathbf{2} \\
(\mathrm{Y})\end{array}$ & $\begin{array}{l}\text { CG/ } \\
\text { PP }\end{array}$ & $\begin{array}{l}\text { Effect } \\
(\mathbf{Y} / \mathbf{X})\end{array}$ & $\begin{array}{c}\text { R } \\
\text { squared }\end{array}$ & $\begin{array}{l}\text { Percent } \\
\text { effect in } \\
\text { year } 2\end{array}$ & $\begin{array}{l}\text { Percent } \\
\text { effect in } \\
\text { year } 2.5\end{array}$ & $\begin{array}{c}\text { Percent } \\
\text { effect in } \\
\text { year } \\
3.33\end{array}$ & $\begin{array}{l}\text { Percent } \\
\text { effect in } \\
\text { year } 5\end{array}$ \\
\hline China & CG & $\rightarrow$ & China & PP & $1 \%$ & $61 \%$ & $34 \%$ & $9 \%$ & $17 \%$ & $61 \%$ \\
\hline Hong Kong & CG & $\rightarrow$ & Hong Kong & PP & $0.02 \%$ & $70 \%$ & $0 \%$ & $65 \%$ & $73 \%$ & $70 \%$ \\
\hline Hong Kong & $\mathrm{CG}$ & $\rightarrow>$ & China & $\mathrm{CG}$ & $1.3 \%$ & $70 \%$ & $0 \%$ & $70 \%$ & $36 \%$ & $52 \%$ \\
\hline Hong Kong & $\mathrm{CG}$ & $\rightarrow$ & China & PP & $1.3 \%$ & $33 \%$ & $7 \%$ & $33 \%$ & $2 \%$ & $4 \%$ \\
\hline
\end{tabular}

FIGURE 13 Comprehensive analysis of corporate governance, offshore incorporations and the interaction between Hong Kong and the Mainland

Note: The figure shows the way that changes in the wave-like patterns in Hong Kong (variable $x$ ) in the factors shown above correlate with the wave-like patterns on the Mainland (denoted as $y$ ). CG refers to the corporate governance proxy for each jurisdiction and PP represents the Panama Papers' recorded number of offshore incorporations. Readers familiar with statistics will recognise these as the results of bi-variate Fourier analysis. We take the "coherency" between these variables as the $\mathrm{R} 2$ and "gain" as the coefficient of change. The "percent effect" shown in the black boxes on the far right do not add up. They represent the extent to an "impulse" in that time frame. Readers unfamiliar with Fourier analysis only need to read the data like a normal regression-keeping in mind that we used more sensitive, appropriate methods for these time series data.

Other evidence supports the hypothesis that Hong Kong's corporate governance influences corporate governance on the Mainland. Figure 13 shows the extent to which changes in corporate governance pass through to offshore incorporations-both at home and in the other jurisdiction. Changes in corporate governance (as measured by the World Economic Forum's corporate governance indicators) had a much higher correlation (impact?) on offshore incorporations in China - about 5 times higher than in Hong Kong. Yet, Chinese firms seem to adjust their corporate governance more than proportionately for changes in (at the same time as?) Hong Kong's corporate governance. A $1 \%$ change in Hong Kong's corporate governance (or offshore incorporations) results in a $1.3 \%$ change in Mainland corporate governance and/or offshore incorporations. Thus, Hong Kong's corporate governance might have a disproportionately larger impact on the Mainland's corporate governance.

In theory, share price changes should confirm whether low corporate governance scores and higher numbers of offshore incorporations lead to harmful practices like tax evasion. At least we should check. Figure 14 informally looks at the way that share prices reacted when the Panama Papers publicly identified Chinese managers/ investors linked to these companies. The figure does

incorporations which demanders of offshore corporate vehicles might have concurrently sought. 


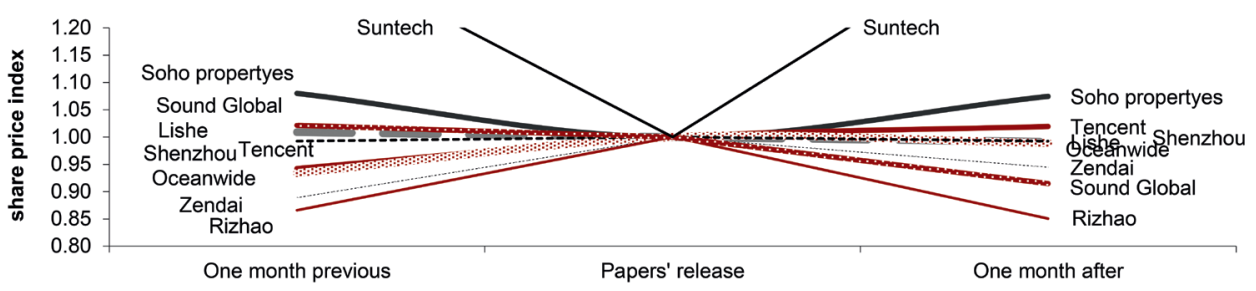

FIGURE 14 Bowtie share price response suggests little real Chinese corporate reaction to Panama Papers revelations

Note: The figure shows the share price index for companies whose senior management and/or investors had been identified in the Panama Papers or the Offshore Leaks. Some companies' share price did better, some worse (before removing the effects of firm-specific and market factors). Nothing about these data suggest any pattern worth investigating further. As described in detail in our paper, some companies probably did better from offshore incorporations and some worse.

SOURCE: BASED ON DATA FROM BLOOMBERG (2016) WITH COMPANIES' IDENTITIES PROVIDED BY THE ICIJ (2016).

not control for general market factors, industry or firm specific effects. These factors would likely have a much smaller impact on a two month study (such as ours), rather than many of the usual multi-year studies. Yet, these results fail to show any clear pattern. Some companies' share prices rose before and after the disclosures which might have affected them. Others share prices fell before and/or after the disclosures. Maybe investors did not see evidence of offshore incorporation as very strong evidence of self-dealing and other problems at these companies? Or-following numerous studies in the vein of Utrero-Gonzalez and Callado-Munoz (2016) ${ }^{31}$ —maybe share prices do not reflect the informativeness of corporate governance practices as fully neoclassical economists might expect. At first glance then, poor corporate governance and wide-spread offshore incorporation seems to pose less risk to Hong Kong's and the Mainland's corporates than one might have thought. More likely - as described in Figure 5 above - corporate governance and offshore incorporation practices in Hong Kong and the Mainland have adjusted

31 Utrero-Gonzalez, Natalia and Francisco Callado-Munoz, Do Investors React to Corporate Governance News? An Empirical Analysis for the Spanish Market. BRQ Business Research Quarterly 19(1) (2016): 13-25. 
to each other and settled down. Revelations of offshore entities' ownerships do not affect the margins of their "sticky governance." (Black et al., 2006). ${ }^{32}$

Such evidence contracts more rigorous evidence supporting a clearer link between tax evasion on the Mainland and share price movements. Chen and co-authors (2016) find that tax evasion/avoidance leads to declining market values, unless the corporate board is skilled enough to use the extra money to increase growth opportunities. ${ }^{33} \mathrm{~A}$ different Chen and those co-authors (2014) find that tax evasion ends up decreasing firm value-despite its positive effects on profits and growth. ${ }^{34}$ If tax avoidance helps increase market values by $13 \%$, then losses from self-serving and worries about lack of transparency reduce market values by around $20 \%$ (Ibid., Table 8 ). They see the existing regulations as a mechanism for creating rents-which businessmen extract for reasons too complex to discuss here. Increasing firm transparency and revisions to the tax rules which create tax-evasion-related rents, thus can decrease the value lost from tax evasion. Both sets of evidence though do support the idea that corporate governance practices and offshore incorporations adjust - or have already adjusted - to some level desired on both sides of the border. Even the Panama Papers' disclosure could not significantly move share prices enough to affect either practice.

To what extent do corporate governance practices and offshore incorporations in China and Hong Kong depend on foreign influence, as opposed to simple inertia or internal factors? Figure 15 shows the weight of institutional inertia (or history) versus the effects of external shocks and innovations in leading to changes in corporate governance and/or offshore incorporations. Both corporate governance and offshore incorporations appear very heavily influenced by external factors-much more than past actions on corporate

32 In contrast, the same author in another study with another co-author (Black and Khanna, 2007) find a share price reaction, in all likelihood because India did not have the same influence from abroad like China had with Hong Kong. Thus, corporate governance reforms provided new information, which led to new share prices. Without further research though, such an assertion remains conjecture. Black, Bernard, Ha-Sung Jang, and Woo-Chan Kim, Predicting Firms' Corporate Governance Choices: Evidence from Korea. Journal of Corporate Finance 12 (2006): 660-691; Black, Bernard and Vikramaditya Khanna, Can Corporate Governance Reforms Increase Firm Market Values? Event Study Evidence from India. Journal of Empirical Legal Studies 4 (2007): 749-796.

33 Chen, Zhang, Cheong-Kee Cheok, and Rajah Rasiah, Corporate Tax Avoidance and Performance: Evidence from China's Listed Companies. Institutions and Economies 8(3) (2016). Available online.

34 Chen, Xu-Dong, Na Hu, Xue Wang , and Xiao-Fei Tang, Tax Avoidance and Firm Value: Evidence from China. Nankai Business Review International 5(1) (2014). Available online. 


\begin{tabular}{|c|c|c|c|}
\hline Jurisdiction & Explanation & $\begin{array}{l}\text { History } \\
\text { (p) }\end{array}$ & $\begin{array}{l}\text { External } \\
\text { shocks } \\
\text { (q) }\end{array}$ \\
\hline \multicolumn{4}{|l|}{ Corp Gov } \\
\hline Hong Kong & No dependence on past reforms and improves with external events & 0 & 0.98 \\
\hline Thailand & Improves with external events & 0 & 0.98 \\
\hline UK & Reflects most past reforms & 0.8 & 0 \\
\hline \multicolumn{4}{|c|}{ Panama Incorporations } \\
\hline China & Offshore incorporations fall on external events & 0 & -0.98 \\
\hline Thailand & $\begin{array}{l}\text { Offshore incorporations fall on external events } \\
\text { Offshore incorporations depend mostly on history/past experience and offshore }\end{array}$ & 0 & -0.98 \\
\hline UK & incorporations fall on external events & 0.83 & -0.99 \\
\hline \multicolumn{4}{|l|}{ Effects * } \\
\hline China & Effect of corporate governance on offshore incorporations & $1 \%$ & $61 \%$ \\
\hline Hong Kong & $\begin{array}{l}\text { Effect of corporate governance on offshore incorporations } \\
\text { Correlation between a change in Hong Kong's corporate governance relative to }\end{array}$ & $0.02 \%$ & $70 \%$ \\
\hline $\mathrm{CN} / \mathrm{HK}$ & China's. & $1.26 \%$ & $16 \%$ \\
\hline $\mathrm{HK} / \mathrm{CN}$ & Correlation between a change in China's offshore incorporations to Hong Kong's & $1.34 \%$ & $32 \%$ \\
\hline
\end{tabular}

FIGURE 15 What causes changes in corporate governance and offshore incorporations? a Other countries exhibited no significant effects.

Note: The figure shows the effects of ARIMA (or auto-regressive, integrated moving average) analysis. Such analysis hopes to show the way the past (as reflected in auto-regressive values) affects a variable relative to outside influences (the moving average part). The last part of the figure shows "effects" as simple correlations of a type of analysis known as multivariate Fourier time series analysis. We do not describe that procedure in-depth, as we can interpret the mean squared coherence as a simple correlation coefficient.

governance/offshore incorporations. The Mainland's corporate governance and offshore incorporations correlate very strongly with Hong Kong's. In contrast, comparator countries like Taiwan, Thailand and the UK seems to have corporate governance influenced more by external events and offshore incorporations influenced by lethargy or pre-existing trends and relationships.

\section{Conclusion}

Do corporate governance practices in one jurisdiction affect those in another jurisdiction? In this paper, we looked at the "correlation" between offshore incorporations of Hong Kong and Mainland companies and broader indicators of corporate governance. Such a correlation actually consisted of the way 
these variables affect each other across the border, the way levels affected rates of change (bringing in differential equations into the analysis) and over time (bringing in auto-regressive and Fourier techniques). We use these data to illustrate our argument-rather than to claim we know something about the exact way these variables affect each other. Corporate governance practices in one jurisdiction like Hong Kong do affect those in another like China. We also reviewed evidence from other scholars, to show such a result does not reflect a particular type of analysis or a statistical artefact. Hong Kong causes (in the statistical time series sense of the word) poor, and eventually better, corporate governance on the Mainland-a strong statement indeed. Corporate governance in both places "settled down" (reached an equilibrium and maintained a steady relationship) in a way that we would expect if corporate governance practices were transmitted over borders. Further research can help find out why these relationships in the data might exist and change over time.

\section{Acknowledgements}

The authors would like to thank The University Grants Committee ThemeBased Research Scheme grant 'Enhancing Hong Kong Future as a Leading International Financial Centre' for funding. 